\title{
The Value Orientations of Minority and Non-Minority Small Business Owners
}

\author{
Cathy A. Enz \\ Cornell University \\ Marc J. Dollinger \\ Indiana University \\ Catherine M. Daily \\ Indiana University
}

This study examines value orientations of minority and non-minority small business owners and contrasts their perceived similarity with corporate customers. Six categories of organizational values, including the values of collectivism, duty, rationality, novelty, materialism, and power are examined. Analyses of a sample of 252 small business firms indicate that minority owners differ from non-minority owners in their value orientations; and are significantly different from nonminority owners in the degree to which they perceive organizational value similarity with customers. However, the levels of perceived value similarity with corporate customers did not vary among the minority groups (i.e. blacks, Hispanics, Asians, and Native Americans). An implication is that value orientation may be an important component in the process of aligning the minority business firm with its environment. Further, a value system may be guiding the behavior of the minority small business owners against the overwhelming odds of racial/ethnic dissimilarities.

Organizational value sharing has recently emerged as a critical component in explanations of firm performance and successful strategic planning. According to Bamberger (1986). values guide the search for problem-solving information and direct the process of organizational coordination and stability. Wakhlu (1986) suggests that an organization's values provide the justification for specific organizational actions. It has even been suggested that the lack of value similarity between the firm and its customers may seriously harm the successful implementation of strategies. While it is generally acknowledged that strategy requires alignment with the firm's environment, the value dimension of that environment is often overlooked (Schwartz \& Davis, 1981; Enz, 1989).

Many researchers are beginning to acknowledge the critical role of value similarity in guiding intraorganizational activities in large firms (Posner, Kouz.es, \& Schmidt, 1985; Enz, 1988; Hambrick \& Brandon, 1988). Regrettably, little empirical work exists that: (1) specifically addresses organizationbased value similarity; (2) concentrates on small businesses; or (3) considers perceived value fits with customers. Even more unfortunate is (4) the virtual neglect of comparative studies on minority- versus nonminority-owned firms (Mescon, Stevens, \& Vozikis, 1984).

Perceived value similarity with the customer may be a mechanism of environmental alignment, since the success of small businesses depends to a large extent on how they interact with external constituencies, the customer being one of the most critical (d'Amboise \& Muldowney, 1988). The small business is vulnerable to changes in customer needs and wants; therefore, expressing values similar to those of the customer may produce the image of likeness or identification. Expressing similar values may be a symbolic way for minority-owned small business enterprises to adapt to customer expectations of successful suppliers. 
The present study addresses the four deficiencies of previous work by empirically exploring perceived organizational value similarity with the primary customer and the degree of importance attached to various values in a comparative study of minority- versus non-minority-owned small businesses. Research comparing minority-owned businesses with their non-minority counterparts continues to show that marketplace parity has not been achieved (Bates, 1985). Vestiges of discrimination continue to surface as one explanation of differences in ability to compete in the economy. Recent reports indicate that minority-owned businesses have made only modest gains in recent years and the number of black-owned small businesses is actually declining (Sonfield, 1986).

The first question of interest in this study concerns the extent to which minority versus nonminority owners of small businesses perceive different organizational values as important. Are there fundamental value differences between minority small business owners (MBEs) and non-minority small business owners (SBEs)? Previous research has been inconsistent on this question. One early study reported that whites and blacks have different value orientations (Goodman, 1969), Later studies found that white and black managers identified the same personal values as important (Watson \& Barone, 1976). In the present study we will examine whether MBEs and SBEs are similar or different in their identification of the importance of various organization-based values.

I the second question of interest here is how minority small business owners compare with their non-minority counterparts in their perceived value similarity with customers? Strategically, it is expected that a high degree of perceived value similarity with corporate customers is necessary to position the small business firm competitively in its market. If values play the critical role they are argued to play in determining attitudes and outcomes, it would seem to be important to know whether minority owners differ from non-minority owners on expressed value similarity with the customer. It may be necessary tor the minority businessperson to espouse higher levels of value similarity in order to fit corporate customers' conceptions of a successful supplier. Non-minority owned firms may be in a better position to rely on other factors, such as attraction or cultural similarity, to enhance their marketplace image, while minority owners express similar organizational values to reduce social distance and compensate for cultural dissimilarity.

The need to be value similar or to express value similarity with powerful customers may be more critical to the minority enterprise than the non-minority firm because of racial and cultural stereotypes and bias. Minority business owners may find their firms are very visible to their customers as representatives of their racial or ethnic category, but not visible for their distinctive competencies or ability to provide a good product or service (Ranter, 1977). The MBE may need to put in extra effort to communicate the value fit with the customer in order to diminish the effects of racial and ethnic differences. Expressing value similarity serves to highlight commonalities and diminish the effects of racial differences.

Finally, this paper explores the question of whether minority business owners differ from each other on organizational values. Asians, for example are the most rapidly growing category of minority small business owners (Bates, 1985). Does the growth of this group have anything to do with levels of value similarity with their customers? Do members of this group differ from other groups of minorities? By comparing blacks, Hispanics, Asians, and Native Americans this study seeks to explore the role of value similarity for culturally and racially distinct groups of minority business owners. 


\section{ORGANIZATIONAL VALUE SIMILARITY}

Organizational value similarity is defined here as the degree of agreement or fit between two parties on the means and ends organizations "ought to" or "should" identify in the operation of the firm. This definition is consistent with the value of conceptualizations of numerous theorists who treat values as preferences or prescriptive beliefs about what should be desirable (Kluckholn, 1967; Rokeach, 1968; Beyer, 1981; Enz, 1986). This approach to the study of values focuses attention on organization- specific values as opposed to work, personal, interpersonal or social values. Further, this definition stresses the degree of perceived value fit.

In a recent synthesis of the literature, Hambrick and Brandon (1988) offer a core set of executive values. This set of value dimensions was devised to facilitate theory building and to advance research in a consistent and logical fashion. Based on the major frameworks of previous researchers, these authors devised six value dimensions or categories. The categories are defined by Hambrick and Brandon as follows (1988, p. 14):

1. Collectivism - to value the wholeness of humankind, regard and respect for all people.

2. Duty -to value the integrity of reciprocal relationships, obligation, and loyalty.

3. Rationality - to value fact-based, emotion-free decisions and actions.

4. Novelty-to value change, the new, the different.

5. Materialism - to value wealth and pleasing possessions.

6. Power-to value control of situations and people.

The present study will focus on the degree of importance of these value dimensions and perceived value similarity with customers on the six dimensions. The Hambrick and Brandon scheme was selected for use because it offers a framework for synthesizing previous values work. However, this investigation does not attempt to explicitly offer hypotheses for each of the value dimensions, since existing theory and empirical exploration do not exist to inform statements of directionality or difference.

Both minority and non-minority small business owners are the focus of this study. One reason for focusing on owners is the ability to make racial and ethnic comparisons in which the respondents' decision-making powers and autonomy are relatively comparable. For example, it would be problematic to compare black and white managers' values if the black manager worked in a white firm in which fear of reprisal or manipulation could prejudice responses. Hence, the minority and non-minority small business owners are in comparable power positions with similar organizational responsibilities and autonomy.

The primary customer was selected as the focus of value similarity because small business owners spend a great deal of time and effort managing this relationship (Dellinger, 1985). Asking the small business owners to think of value fits with the leaders of these corporations allows for a symbolic human referent for embodying the overriding values adopted in the customer organization. A growing body of literature suggests that the CEO's values define those of the firm and have a tremendous impact on the direction and mission of the firm (Hambrick \& Mason, 1984; Enz, 1988; Hambrick \& Brandon, 1988). By embedding and then transmitting the organization-based values, leaders maintain their overarching preferences and beliefs (Schein. 1985). Since top managers embody the organization's values, it seems reasonable to ask MBE/SBE owners to think of how their organizational values are similar to those of the leaders of the primary organization with-which they do business. Contact with the CEO is not a prerequisite for assessing perceived value similarity because the executives and the overall values driving 
the firm are tightly coupled.

\section{RESEARCH QUESTIONS}

It has been suggested that many white Americans maintain an image of the minority businessperson as lacking in managerial skills and abilities (Williams, 1988). This view may contribute to fewer opportunities for the minority small business owner. As Son- field argues, "If truly equal opportunity could be made available to black and white small businessmen, then blacks could be as successful as whites" (1978, p. 44), With the view of minorities as disadvantaged or dissimilar, the ability of their businesses to prosper in the market is in question. Hence, dissimilarity, not ability, may be a cause of lowering minority-owned business success.

Little previous work has examined value differences between minority and nonminority owners of small business firms. One of the few studies that compared the personal values of black and white owners of small businesses found that black and white owners possessed similar general value orientations (Watson \& Simpson, 1978). This work was an extension of an earlier values study conducted within large corporate settings (Watson \& Barone. 1976).

While some evidence exists to suggest that black and white small business owners identify the same set of personal values, we have yet to learn if they differ on organizational values or whether they differ in their perceptions of similarity with corporate customers. It is possible that minority and nonminority owners identify as important the same set of organizational values, but differ in their perceptions of value fit with their corporate customers.

In summary, the study will attempt to answer the following questions:

1. Do minority owners differ from non-minority owners in their identification of important organizational values?

2. Do minority owners differ from non-minority owners in their perceived value similarity with customers?

3. Do minority owners from different ethnic/racial backgrounds differ from each other on the degree of perceived value similarity with corporate customers?

\section{METHOD Data Collection}

Minority business enterprises (MBEs) were surveyed at random from the Try Us '88: National Minority Business Directory (Kahnk, 1988). This directory lists minority firms that wish to participate in the special minority procurement programs that many large corporations have established. This is the ideal target group for this study because it consists of minority owners who believe they have the capabilities to provide goods and services to major corporate customers. Four hundred seventy-five surveys were sent; 153 usable responses were received (two mailings), for a response rate of $32.2 \%$.

A group of small businesses (SBEs) was selected at random from Harris's Industrial Directory of Indiana (1988) and sent the identical survey, except for the substitution of the acronym "SBL" for "MBE" in each item. Four hundred eighty surveys were sent 


\section{Table 1}

\section{The Representativeness of the Sample: A Comparison of Respondents (R) versus Non-respondents (NR)}

\begin{tabular}{|c|c|c|c|c|c|c|}
\hline \multirow[b]{2}{*}{ Group } & \multicolumn{2}{|c|}{$\begin{array}{c}\text { Sales } \\
(\$ 1000)\end{array}$} & \multicolumn{2}{|c|}{$\begin{array}{c}\text { Employees } \\
\text { (Number) }\end{array}$} & \multicolumn{2}{|c|}{ t-Value } \\
\hline & $\mathbf{R}$ & NR & $\mathbf{R}$ & NR & Sales & Employees \\
\hline & Mean & Mean & Mean & Mean & & \\
\hline SBE & $\begin{array}{c}7,572 \\
(24,196)\end{array}$ & $\begin{array}{c}2,281 \\
(5,623)\end{array}$ & $\begin{array}{c}44.0 \\
(42.2)\end{array}$ & $\begin{array}{c}49.5 \\
(50.4)\end{array}$ & -1.50 & 1.14 \\
\hline MBE & $\begin{array}{c}2,430 \\
(4,054)\end{array}$ & $\begin{array}{c}2,325 \\
(3,926)\end{array}$ & $\begin{array}{c}33.3 \\
(75.1)\end{array}$ & $\begin{array}{c}31.1 \\
(61.1)\end{array}$ & -.24 & -.33 \\
\hline
\end{tabular}

Standard errors in parentheses.

(two mailings), and 99 usable responses were received, for a response rate of $20.6 \%$. The response rate for SBEs was lower than for the MBEs because the questionnaire did not have the same salience for the SBEs. This is believed to be because several questions, not relevant to this study, focused on purchasing programs, and fewer nonminority SBEs participate in specially designed corporate SBE purchasing programs.

\section{Sample Characteristics}

The data collected retied on directories as the sources of subjects, making it possible to test each sub-sample for its representativeness. ${ }^{1}$ Table 1 shows that, based upon firm sales and the number of employees, there were no statistical differences between respondents $(R)$ and non-respondents (NR) for the SBE $(t=1.50, t=1.14)$ and the MBE $(t=.24, t .33)$ groups. The SBE firms were, however, larger than the MBE firms in sales (not statistically significant) and number of employees $(t=5.13, p<.001$ ).

The personal characteristics of the respondents from the two groups of small businesses are summarized in Table 2 . In both minority and non-minority businesses, the respondents were predominantly male, in their mid to late forties, with over ten years in the business. Only $19 \%$ of the nonminority owners were women. The MBEs were mostly owned by blacks and Hispanics, with smaller percentages owned by Asians and Native Americans. Minority owners were more highly educated than their non-minority counterparts and slightly younger.

Since differences in demographic characteristics could confound the value differences between

\footnotetext{
${ }^{1} \mathrm{MBE}$ responses were received from owners throughout the United States, while SBE responses were restricted to the state of Indiana. A comparison of Midwestern-based MBEs with the Indiana SBEs produced the same results as the national sample reported in the body of this paper. In addition, Midwestern MBEs were not significantly different from the rest of the national MBE sample. Hence, the potential errors of incomparability between a national MBE and a regional SBE sample were not factors in this study.
} 
minority and non-minority small business owners, several t-tests for

\section{Table 2}

\section{Sample Characteristics and Differences in Demographic Profiles of Minority and Non-Minority Small Business Owners}

\begin{tabular}{llll}
\hline & MBE & SBE & t-tests \\
\hline Sample Size & 153 & 99 & \\
Age & 45 & 48 & 1.85 \\
Tenure & 11 years & 13 years & 1.61 \\
Gender & & & \\
$\quad$ Males & $75 \%$ & $81 \%$ & .79 \\
$\quad$ Females & $25 \%$ & $19 \%$ & \\
Education & $1 \%$ & & \\
Less than H.S. & $10 \%$ & $2 \%$ & \\
High School & $27 \%$ & $28 \%$ & \\
Some College & $22 \%$ & $35 \%$ & \\
College Grad. & $14 \%$ & $6 \%$ & \\
Grad. School & $26 \%$ & $15 \%$ & \\
$\quad$ Grad. Degree & & & \\
Race & $0 \%$ & $100 \%$ & \\
$\quad$ White & $45 \%$ & & \\
Black & $30 \%$ & & \\
Hispanic & $20 \%$ & $5 \%$ & \\
Asian & & & \\
Native American & & & \\
\hline
\end{tabular}

$* \mathrm{p}<.05$

demographic differences were conducted. As Table 2 indicates, MBE and SBE respondents did not differ by age, tenure in their organizations, or sex. Differences in educational levels were found $(t=2.31 ; p<$ .05). Minority entrepreneurs were a significantly better educated group then their non-minority counterparts. Since the survey form was relatively long and fairly complicated, it is possible that individuals with lower levels of educational attainment were under-represented in the sample. The high percentage of minority respondents with graduate degrees (26\%) suggests that minorities who might be blocked in career opportunities or financial rewards in large corporations have found an alternative in self-employment. Regardless of the reasons for the education gap, the differences revealed in this preliminary analysis will be controlled in later analysis by using education as a covariate.

Since census data has suggested that demographic differences may exist within the minority community between ethnic groups, we conducted several ANCOVAs to check. These analyses indicated that blacks, Hispanics, Asians, and Native Americans did not differ in age ( $F=.15 ; p=.93)$, tenure in their organization $(F=1.64 ; p=.18)$, or $\operatorname{sex}(F=1.22 ; p=.30)$. Significant differences were found in educational levels $(F=6.76 ; p=.0003)$ and place of birth $(F=4,07 ; p=.008)$. Asians possessed the highest levels of educational attainment (graduate school), while Native Americans possessed (he lowest levels (some college). Hispanics reported being born in large cities, in contrast to Native Americans, who were born in rural areas. Both Asians and blacks were, on the average, born in small cities. Given these 
preliminary findings, in the analyses to follow we will include education and place of birth as covariates in order to clarify the within-minority-group value comparisons. One final concern was whether the degree to which the MBEs sold to large corporations would affect perceptions of value similarity with the customer. Preliminary analysis revealed no differences in value similarity as a result of current customer sales activity. ${ }^{2}$

The owner of the small business was the respondent for each company surveyed because this person was considered to be the most knowledgeable about the firm and the primary communicator with critical external constituencies (i.e. corporate customers). Although only one person was sampled from each firm studied, this was considered appropriate because of the critical role founders and owners play in shaping values (Schein, 1985). Further, previous research suggests that the perceptions of only one person within each organization may represent "noise" in the analysts, but not systematic bias of the responses (Grinyer \& Yasai-Ardekani, 1980).

\section{Measures}

The Organizational Value Congruity Scale (OVC) developed by Enz (1986) was used in this research to capture six categories of organizational values. The OVC consisted of 20 items arranged in six categories, following the core set of executive values identified by Hambrick and Brandon (1988) as: Collectivism ( 3 items), Duty ( 4 items), Rationality ( 3 items). Novelty ( 4 items), Materialism ( 2 items), and Power ( 3 items). One item on the OVC was omitted because it did not fall within the Hambrick and Brandon framework.

Two separate approaches to organizational values were possible from the OVC. First, respondents were asked to indicate how important each of the 20 organizational values were to them, using a 5point, Likert-type scale ranging from "Not at all important" to "Extremely important." The internal consistency reliabilities (Cronbach alphas) for the value importance scale were .89 for the minority sample and .81 for the non-minority sample. The 20 values were then grouped into the six value categories and summed to obtain a value importance score for each. A second measure, capturing perceived agreement, was obtained by asking respondents to indicate their degree of similarity with the top management of their primary large corporate customer. This measure employed a 5-point scale ranging from "Very Dissimilar" to "Very Similar." The value similarity with the primary customer scale yielded alphas of .91 and .82 , respectively, for the minority and non-minority samples. As with the importance scale, the values items were sorted into the six value categories and summed to obtain measures of perceived value congruity with the primary customer.

\section{RESULTS}

In order to answer the first research question of whether owners of minority firms differ from nonminority owners in their identification of important organizational values, six ANCOVAS were performed. Table 3 presents the ANCOVAS for differences in the importance of the six types of values between the

\footnotetext{
2 Six ANCOVAs were performed to explore the question of value differences based on customer selling. Using directory data, MBEs were grouped by whether they (1) did not currently sell to big businesses. (2) sold to one, (3) sold to two, or (4) sold to three or more big businesses. These analyses indicated that value similarity on all six types of values did not vary by the degree to which respondent MBEs were already selling to large corporations (Collectivism $F=.52, p=.66$; Duty $F=1.24$. $p .30$; Rationality $F=.61$ : $p .61$; Novelty $F=1.10 . p=.35$ : Materialism $F=.41, p=.75 ;$ and PowerF $=.53, p=.66)$.
} 
two groups of small businesses, with education as the covariate. Significant differences were found for all of the categories of value importance. Owners of minority firms attached significantly more importance than non-minority owners to the values of collectivism (respect for all people), rationality (emotion-free decision making), materialism (wealth), duty (obligation and loyalty), novelty (change), and power (control of situation and people).

\section{Table 3}

\section{ANCOVA for Importance of Value Types for Minority- and Non-Minority-Owned Small Businesses, Controlling for Education}

\begin{tabular}{|c|c|c|c|c|c|c|}
\hline \multirow[b]{2}{*}{$\begin{array}{l}\text { Value } \\
\text { Types }\end{array}$} & \multicolumn{2}{|c|}{ MBE } & \multicolumn{2}{|c|}{ SBE } & \multicolumn{2}{|c|}{ F-values } \\
\hline & $\mathbf{N}$ & Means & $\mathbf{N}$ & Means & $\begin{array}{l}\text { Education } \\
\text { Covariate }\end{array}$ & $\begin{array}{l}\text { Main } \\
\text { Effect }\end{array}$ \\
\hline Collectivism & 128 & 11.34 & 91 & 9.84 & 2.14 & $30.15^{* *}$ \\
\hline Duty & 128 & 16.77 & 91 & 15.87 & .03 & \\
\hline Rationality & 128 & 13.16 & 91 & 11.62 & .08 & $29.45^{* *}$ \\
\hline Novelty & 132 & 16.45 & 91 & 14.54 & .72 & $20.92 * *$ \\
\hline Materialism & 132 & 8.41 & 91 & 7.48 & 1.42 & $18.40^{* *}$ \\
\hline Power & 132 & 12.23 & 91 & 11.21 & .47 & $11.11^{* *}$ \\
\hline
\end{tabular}

$$
\begin{gathered}
* \mathrm{p}<.05 \\
{ }^{* *} \mathrm{p}<.001
\end{gathered}
$$

Worthy of note are the consistently higher mean importance scores for MBEs versus SBEs, indicating that the minority owners attached greater importance to each of the values regardless of the owners' levels of educational attainment. Further, the substantial differences between MBEs and SBEs on the importance of collectivism (i.e., respect for all people) may provide some indication of the greater sensitivity of minority small businesspersons to individual differences, as well as to cultural and ethnic diversity.

To examine the second research question, whether these two groups of owners differ on the degree of similarity they possess with their primary customer, several ANCOVAs were performed with education as the covariate (see Table 4). These analyses show significant differences in value similarity for all but one category of values. Minority small business owners expressed higher levels of value similarity with their customers on all six value dimensions and significant differences from SBEs on five of the six dimensions. Valuing the integrity of reciprocal relationships, obligation, and loyalty, as captured by duty, was the only value type for which non-minority owners were not significantly lower than minority owners in expressed similarity with the customer. Since the items focused on similarity with customers, this result would seem to indicate that "duty" is a core value orientation for all small businesses in the market exchange. Both groups, minority and non-minority owners, share in the value of loyalty and obligation to their customers. Overall, the findings suggest that the perception of minority 
owners differs from that of non-minority owners in the identification of important organizational values and espoused value similarity with customers.

The findings clearly show that the effects of the covariate (education) are not significant for any of the comparisons of MBE and SBE assessments of value importance or perceived value similarity with the customer. Hence, the relationships between educational attainment and value importance or perceived similarity are not significant. Further, small business owners' membership in a minority group does affect the degree of value importance and perceived customer fit they espouse, even when correcting for initial differences in education.

\section{Table 4}

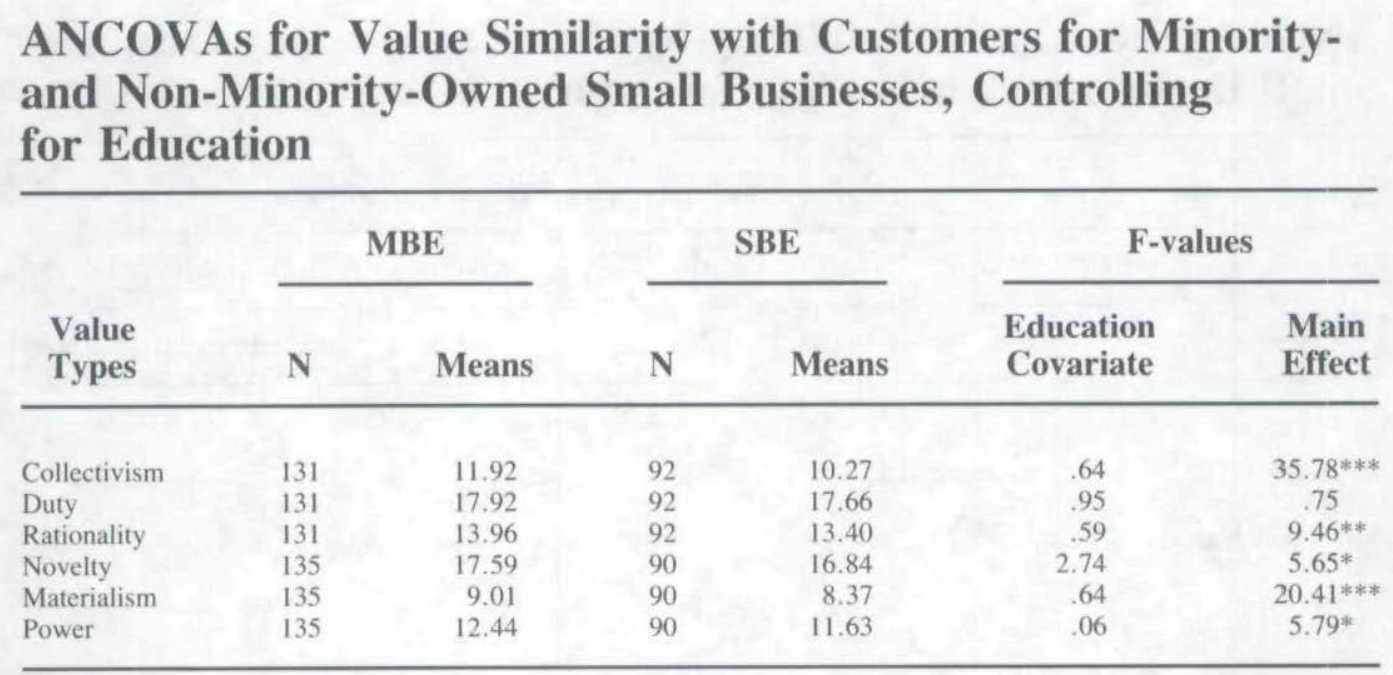

$$
\begin{aligned}
& { }^{*} \mathrm{p}<.05 \\
& { }^{* *} \mathrm{p}<.01 \\
& * * * \mathrm{p}<.001
\end{aligned}
$$

As a final analysis to address the third research question, the minority firms were stratified by cultural/ethnic background to see if value differences exist based on race or cultural heritage. Table 5 summarizes the ANCOVAs performed for each value category with education and place of birth as covariates. Significant differences in value similarity were not found on the basis of race or cultural background; hence blacks, Hispanics, Asians, and Native Americans did not differ in their appraisals of value similarity, when taking into account demographic differences. Although significant differences were not evident. Native Americans expressed the highest levels of similarity on the values of rationality, novelty, materialism, duty, and power. Hispanics expressed the highest similarity on the value of collectivism, and the lowest similarity on the values of rationality and novelty.

These findings seem to suggest that, despite wide cultural differences in backgrounds, all minority groups tended to regard themselves as value similar to their major corporate customers. Although some minority groups may face economic barriers to entrepreneurship, they appear to express higher levels of value similarity with the customer than non-minority owners. Minority business persons may be aligning 
their organization-based values with their customers as a means of competitive advantage in a turbulent environment.

Blacks, Hispanics, Asians, and Native Americans were different in levels of education and the location of birth, but these factors did not significantly alter their agreement in perceiving themselves as value-similar to their corporate customers. When controlling for these demographic factors, this study found no differences in perceptions of value similarity, suggesting the possibility that a powerful socialization mechanism is at play in minority groups to lower barriers that might separate them from the mainstream of the American economy.

\section{Table 5}

\section{ANCOVAs for Value Similarity by Race for Minority-Owned Small Businesses, Controlling for Education and Place of Birth}

\begin{tabular}{|c|c|c|c|c|c|c|}
\hline \multirow[b]{3}{*}{ Race } & \multicolumn{6}{|c|}{ Value Similarity with Primary Customer } \\
\hline & Collectivism & Duty & Rationality & Novelty & Materialism & Power \\
\hline & Means & Means & Means & Means & Means & Means \\
\hline Black & 11.27 & 16.28 & 13.18 & 16.36 & 8.28 & 12.16 \\
\hline Hispanic & 11.45 & 16.89 & 12.84 & 16.24 & 8.52 & 12.24 \\
\hline Asian & 11.43 & 17.48 & 13.33 & 16.87 & 8.35 & 12.17 \\
\hline Native American & 11.13 & 17.63 & 14.00 & 17.00 & 8.88 & 12.75 \\
\hline F-value & & & & & & \\
\hline Education & 1.58 & .21 & .19 & 1.68 & 1.06 & .01 \\
\hline Place of Birth & .47 & 2.26 & .13 & .03 & .21 & .14 \\
\hline Main Effect & .27 & 1.57 & .84 & .20 & .41 & .12 \\
\hline
\end{tabular}

$\mathrm{p}<.05$

In sum, the findings show that minority business owners attach greater importance to organization- based values than do their non-minority business counterparts. In addition, minority owners differ from non-minority owners in the expression of value similarity with the critical customer. Across all but one value dimension minority small business owners indicated greater value similarity with their customer. Finally, differences in racial and cultural backgrounds of minority owners did not alter the degree of expressed value similarity with the customer, nor did differences in demographic factors.

\section{DISCUSSION AND IMPLICATIONS}

This study investigated three questions: (1) whether the minority owners of firms differed from non-minority owners in their identification of the importance of specific organizational values; (2) whether they differed in their perceived value similarity with large corporate customers; and (3) whether minority owners differed from each other. The results indicate that minority owners both attached more importance to the six types of organizational values, and perceived themselves as more value-similar to their corporate customers than their non-minority counterparts. The results also reveal that minority 
owners did not differ from each other on the degree of perceived value similarity with the customer. Differences in education and birth location (i.e. urban vs. rural) did not influence the findings and were thus insignificant.

In contrast to the previous research, which found that black and white owners had similar personal values (Watson \& Simpson, 1978), the present study suggests that minority owners might be more value-similar to corporate America than non-minority owners. While this study examines organizational rather than personal values, it reaches a conclusion similar to that of previous work on personal values, that minority owners do not view themselves as being at odds with mainstream corporate leaders. In fact, this study suggests that minorities, even when differing from each other in education and birth location, more strongly identify with values derived from studies of white corporate America than do non-minority small business owners.

The consistently higher levels of perceived value similarity with the customers for minority owners may be the result of a need to reduce boundaries and tendencies to polarize by race or ethnic background. If values play a critical role in determining attitudes and outcomes, it may be a logical competitive strategy to adopt and express values in concert with corporate executives. While value similarity is important to non-minority firms too, especially for the "duty" value, it is vital to minority firms as an equalizer. One explanation for this finding is that minority owners lack other means of being "like" their customer groups and must find some element of comparability in order to legitimize their enterprise and engender confidence. By expressing similar values minority owners may be symbolically communicating their willingness and ability to fit within the mainstream of American enterprise. It is also possible that they actually fit more closely into the mainstream values of corporate America than do white small business owners. Because minority entrepreneurs seldom share racial and cultural backgrounds with their primary customers, one of the ways they build trust and alleviate the uncertainty of doing business is by sharing values.

This argument is strengthened by the finding that all four of the minority groups studied here were similar in their high levels of espoused similarity with customers, regardless of demographic differences. The implication is that a homogenizing process is underway in the business community in the area of values. This integration may be occurring between small minority firms and their corporate customers, suggesting that a "value system" may be guiding MBBs' actions against overwhelming impediments to success. However, the relationship between non-minority small business owners and their minority counterparts is more problematic. Here value differences exist and, in the absence of interaction between the two groups of owners, are likely to remain. Whether or not these differences can be used as a basis for competitive advantage or merely reflect past historical and cultural idiosyncracies is unclear.

\section{CONCLUSIONS}

The present investigation made a contribution to the study of values by addressing four deficiencies of previous work. These deficiencies included: (1) a lack of empirical tests regarding organizational values; (2) exclusive focus on large firms; (3) exclusive attention to intraorganizational versus interorganizational value similarities; and (4) a neglect of comparisons between minority and nonminority firms. While this study is preliminary in nature, it has addressed these limitations.

Further exploration is needed to determine whether value similarity results in greater success for the minority firm. One question of particular interest is whether value similarity will help MBEs if they lack capital or expertise. Does value similarity enhance performance or corporate assessments of 
performance? Researchers interested in small businesses might consider exploring the role of value similarity versus managerial skills in affecting critical outcomes.

\section{REFERENCES}

Bamberger, 1, (1986). Values and strategic behavior. Management International Review, 26, 57-69.

Bates, T. (1985). Impact of preferential procurement policies on minority-owned businesses. Review of Black Political Economy. 14, 51-65.

Beyer, J. < 1981). ideologies, values, and decision making in organization. In P. C. Nystrom \& W, Starbuck (Eds.). Handbook of organizational design, 2, pp. 166-202. New York: Oxford University Press,

d'Amboi.se. G., \& Muldowncy, M. (1988). Management theory for small business: Attempts and requirements. Academy of Management Review. 13(2). 226-240.

Dol linger, M. (1985). Environmental contact and financial performance of the small firm. Journal of Small Business Management, 23( I), 24-30.

Enz, C. (1986). Power and shared values in the corporate culture. Ann Arbor. MI: UMI Research Press.

Enz, C. (1988). The role of value congruity in intraorganizational power. Administrative Science Quarterly 33, 284-304.

Enz. C. (1989). The relationship between organizational value sharing and influence over strategic decisions. International Journal of Value-Based Management, 2, 79-92.

Goodman. R. A. (1969). A hidden issue in minority employment. California Management Review, II,

Grinyer. P., \& Yasai-Ardekani, M, (1980). Dimensions of organizational structure: A critical replication. Academy of Management Journal, 23, 405-421.

Hambriek, D,. \& Brandon, G. (1988). Executive values. In D. Hambrick (Ed.), The executive effect: Concepts and methods for studying top managers. Greenwich. CT: JAI Press.

Hambriek. D.. \& Mason, P. (1984). Upper echelons: The organization as a reflection of its top managers. Academy of Management Review, 9, 193-206.

Kahnk, L. (1988). Try Us '88: National Minority Business Directory. Minneapolis. MN: National Minority Business Directories.

Ranter, R. M. (1977). Some effects of proportions on group life: Skewed sex ratios and responses to token women. American Journal of Sociology, 82(5), 965-990.

Kluckholn. C. (1967). Values and value-orientations in the theory of action. In T. Parsons \& E. A. Shils (Eds.), Toward a general theory of action, pp. 388-433. Cambridge: Harvard University Press. 
Mescon. T., Stevens. G.. \& Vozikis, G. (1984). Blacks as entrepreneurs: The Liberty City experience. In

Hornaday, Dudley. Timmons, \& Vesper (Eds.), Frontiers of entrepreneurship research, pp, 249-263. Waltham, MA: Babson College.

Posner. B.. Kouzed, J., \& Schmidt, W. (1985). Shared values make a difference: An empirical test of corporate culture. Human Resource Management, 24, 293-309.

Rokeaeh, M. (1968). Beliefs, attitudes, and values, San Francisco: Josscy-Bass.

Schwartz. H., \& Davis, S. M. (1981). Matching corporate culture and business strategy. Organizational Dynamics, 30-48.

Schein, E. (1985). Organizational culture and leadership. San Francisco: Jossey-Bass.

Sonfield. M. (1978), An attitudina! comparison of black and white small businessmen. American Journal of Small Business, 2. 38-45,

Sonfield, M. (1986), An exploratory analysis of the largest black-owned U.S. companies. Journal of Small Business Management, 24, 9-17.

Wakhlu, B. (1986). The importance of values in organization. Management and Labor Studies, II, 262265.

Watson, J., \& Barone, S. (1976). The self-concept, personal values, and motivational orientations of black and white managers. Academy of Management Journal, 19, 36-48.

Watson. J.. \& Simpson. L. (1978). A comparative study of owner-manager personal values in black and white small businesses. Academy of Management Journal, 21, 313-319.

Williams. R, (1988). A buyer's guide to doing business with minority vendors. Proceedings of the National Association of Purchasing Management, pp, 228-240. Tcmpe, AZ: NAPM.

The authors wish to acknowledge the support of the Ameritech Foundation and the Regional Economic Development Institute of Indiana University's School of Environmental and Public Affairs. The helpful comments of Peter Mills and two anonymous reviewers arc gratefully acknowledged. 